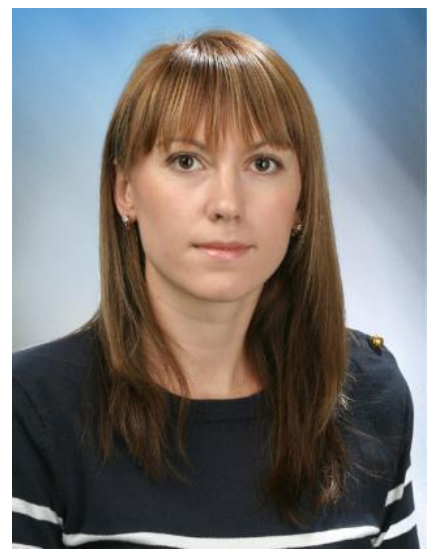

\section{Юлія Ненько,}

доктор педагогічних наук, доцент, завідувач кафедри іноземних мов, Черкаський інститут пожежної безпеки імені Героїв Чорнобиля НУЦЗУ (м.Черкаси, Україна)

\author{
Yuliia Nenko, \\ Doctor of Pedagogi, Associate Professor, Head \\ of the Department of Foreign Languages, Cherkasy \\ Institute of Fire Safety named after Chornobyl Heroes of \\ the National University of Civil Defense of Ukraine \\ (Cherkasy, Ukraine) \\ julia18016@ukr.net \\ ORCID ID 0000-0001-7868-0155
}

УДК 378.015.31.041:37.011.3-052

\title{
ПРОФЕСІЙНИЙ РОЗВИТОК УЧИТЕЛЯ АНГЛІЙСЬКОї МОВИ: ДЕЯКІ ПРАКТИЧНІ АСПЕКТИ
}

\begin{abstract}
Анотація. Метою дослідження $€$ представлення результатів теоретичного аналізу ефективних шляхів професійного саморозвитку та самовдосконалення вчителів англійської мови відповідно до нових освітніх стандартів. Ключовими методами дослідження є теоретичні методи аналізу, синтезу та узагальнення педагогічної та психологічної літератури.

Устаттіпорушенопроблемупрофесійногорозвиткуучителяанглійськоїмови.Розкритотрактуванняпоняття «безперервний професійний розвиток», його характеристики. Автор доходить висновку, що процес професійного становлення та розвитку вчителів має набути ознак безперервності, наступності на різних його етапах, створювати передумови для задоволення як освітніх потреб особистості вчителя, так і соціального замовлення на якісну підготовку компетентного фрахівця та сприяти побудові індивідуальної траєкторії професійного та особистісного самовдосконалення педагога. Проаналізовано теоретичні основи наявних провідних сучасних підходів до організації професійного саморозвитку педагогічних працівників, у тому числі вчителів англійської мови. Це розробка інноваційних моделей і програм підвищення кваліфікації, що відповідають цілісним вимогам до системи підвищення кваліфікації всіх рівнів педагогічних працівників, використання ціннісного потенціалу сучасних освітніх технологій, що обґрунтовує вибір нових підходів і методів іншомовної освіти, проведення науковопрактичних заходів (конференцій, семінарів, вебінарів), залучення вчителів і молодих дослідників до публікації результатів власної дослідницької роботи тощо.
\end{abstract}

Ключові слова: учитель, педагогічний працівник, саморозвиток, розвиток.

\section{PROFESSIONAL DEVELOPMENT OF ENGLISH LANGUAGE TEACHER: SOME PRACTICAL ASPECTS}

Abstract. The aim of the study is to present the results of the theoretical analysis of effective ways of professional selfdevelopment and self-improvement of English language teachers in accordance with new educational standards.

The key methods of research are theoretical methods of analysis, synthesis and generalization of pedagogical and psychological literature. The article addresses the problem of professional development of the English teacher. The interpretation of the concept of «continuous professional development», its characteristics are revealed.

The theoretical bases of existing leading modern approaches to the organization of professional self-development of pedagogical workers, including English language teachers, have been analyzed. One of the priority directions of the reform of the national education system is the renewal of the teacher's corps, constant professional development of teachers, expansion of professional competencies and improvement of their qualification through formal, informal and informal additional education for professional and personal self-development of pedagogical workers.

The author's consideration of the concept of «continuous professional development of the teacher» leads to the conclusion that the process of professional formation and development of teachers should acquire signs of continuity, continuity at its various stages, create the preconditions for satisfying both the educational needs of the teacher's personality and social order for the qualitative training of the competent specialist and contribute to the construction of an individual trajectory of professional and personal self-improvement of the teacher.

Keywords: teacher, pedagogical worker, self-development, development. 
Постановка проблеми. Проблема сучасного шкільного навчання полягає в тому, що вчителі через постійне та механічне повторення повсякденної педагогічної діяльності відходять від сучасних завдань навчання іноземної мови. Більше того, зміни та реформи, що відбуваються в системі освіти, в тому числі й нові стандарти освіти, спонукають вчителів до прийняття та осмислення освітніх програм, написання доповідей, надання аналітичних даних посадовим особам тощо замість необхідності профресійного саморозвитку.

Крім того, слід вказати на фінансові труднощі, оскільки додаткове навчання, професійна перепідготовка або спеціальні курси підвищення кваліфікації здійснюються за рахунок учителів. Окрім формальних проблем системи професійної освіти, існує ціла низка обмежень у сфері професійної соціалізації та професійного саморозвитку, пов'язаних з відсутністю необхідної інформації та офріційної підтримки, самоорганізації та навичок управління часом, поганий фрізичний стан і навіть проблеми зі здоров'ям.

META I ЗАВДАННЯ ДОСЛІДЖЕННЯ. Метою дослідження $є$ представлення результатів теоретичного аналізу ефективних шляхів професійного саморозвитку та самовдосконалення вчителів англійської мови відповідно до нових освітніх стандартів за умов інтеграції національної системи освіти у світовий освітній простір.

\section{МЕТОДИ ДОСЛІДЖЕННЯ}

Ключовим методом дослідження $€$ аналіз національних освітніх стандартів, професійних освітніх програм та наукових ресурсів. Теоретичні методи аналізу, синтезу та узагальнення педагогічної та психологічної літератури використано з метою з'ясування ступеня розвитку досліджуваного наукового питання.

\section{РЕЗУЛЬТАТИ ДОСЛІДЖЕННЯ}

На основі власного досвіду можна стверджувати, що сучасний учитель англійської мови має безмежні можливості зробити свій професійний освітній шлях розвитку та саморозвитку ефективним, а освітнє середовище протягом усього життя корисним.

Проблема професійного самовдосконалення та саморозвитку досить ґрунтовно представлена в наукових розвідках учених, зокрема В. Андрущенка, Б. Гершунського, І. Зязюна, В. Кременя та ін. (філософський аспект); К. Абульханової-Славської, Б. Ананьєва, А. Бодалєва, Л. Виготського, А. Леонтьєва, С. Рубінштейна, Д. Узнадзе та ін. (психологічний аспект).

Водночас попри значну кількість наукових праць, присвячених особистісному та професійному розвитку та саморозвитку вчителя та неперервному професійному розвитку педагогічних працівників, окремі аспекти проблеми залишаються все ще недостатньо дослідженими.

Безперервний професійний розвиток, на думку сучасних дослідників, є комплексом системних освітніх заходів, результатом яких є вдосконалення професійних компетенцій та оволодіння загальними компетенціями, необхідними на певному етапі професійного розвитку.

Зарубіжне трактування цього поняття виходить з концепції Life Long Learning (з англ. «навчання протягом усього життя»). Безперервний професійний розвиток - означає йти в ногу з сучасними трендами і кращими освітніми практиками. Це основа для продовження професійного вдосконалення особистості педагога і невід'ємна складова розвитку професії в цілому [9].

Значущим, на нашу думку, є твердження О. Новікова щодо заміни формули «освіта на все життя» на фрормулу «освіта через усе життя» [2].

За визначенням Міжнародної комісії з питань освіти для XXI століття при ЮНЕСКО, безперервна освіта має перетворитися в процес безперервного розвитку людської особистості, знань, навичок. Опора на девіз ЮНЕСКО «Освіта для всіх і через все життя» визначила напрямок низки теоретико-методологічних досліджень у вітчизняній та зарубіжній теорії і практиці й отримала подальший розвиток в рамках глобального проекту «Освіта через усе життя: безперервна освіта в інтересах сталого розвитку». При цьому сталий розвиток дефінійовано як «керований збалансований розвиток суспільства, що не руйнує своєї природної основи і забезпечує безперервний прогрес людської цивілізації, це соціально бажаний, економічно життєздатний і екологічно сталий розвиток суспільства» [3]. У межах зазначеного масштабного міжнародного проекту розглянуто завдання професійного розвитку педагога, в тому числі і вчителя іноземної мови [4].

Деякі вчені припускають, що поняття безперервного профресійного розвитку вчителів (англ. continuous professional development) використовується замість поняття «in-service training» та «оn the јоb training», оскільки суб'єктом професійного розвитку є сама особа, що розвивається. Зазначене дозволило змінити концепцію системи підвищення кваліфікації педагогічних працівників, основним завданням якої стає створення умов для саморозвитку.

За твердженням О. Михайлова, саморозвиток $є$ особистісним ресурсом успішності вчителя, вихователя, керівника, освітньої організації [5]. А отже, однією з можливостей, яка повинна бути створена з метою безперервного профресійного розвитку вчителя, $€$ надання широкого спектру освітніх ресурсів, що дозволяють сформувати індивідуальну програму професійного зростання, освіти, незалежно від досвіду професійної діяльності.

Одним із пріоритетних напрямків реформування національної системи освіти $€$ поновлення вчительського корпусу, постійний професійний розвиток учителів, розширення професійних компетентностей і підвищення їхньої кваліфікації через фрормальну, неформальну та інформальну додаткову освіту для професійного та особистісного саморозвитку педагогічних працівників. 
І. Чечель розуміє професійний розвиток як сукупність фрормальної та неформальної освіти протягом усієї трудової діяльності; при цьому формальна освіта є ієрархічно та хронологічно структурованою освітньою системою, що реалізовує освітній процес в офіційних освітніх організаціях, а неформальна освіта, як і інформальна, - це будьяке організоване поза межами закладів освіти навчання, в процесі якого здобуваються знання, набуваються нові цінності, фрормуються навички в результаті взаємодії людини з колегами і суспільством

в цілому, а також засобами масової інформації [8].

Таким чином, розгляд поняття «неперервний професійний розвиток педагога» призводить до висновку про те, що процес професійного становлення та розвитку вчителів має набути ознак безперервності, наступності на різних його етапах, створювати передумови для задоволення як освітніх потреб особистості вчителя, так

і соціального замовлення на якісну підготовку компетентного фахівця та сприяти побудові індивідуальної траєкторії професійного та особистісного самовдосконалення педагога.

Професійний розвиток учителя/викладача англійської мови ґрунтується на аксіології іншомовної освіти, зміст якої об'єднує всі види діяльності: навчальну, методичну, науково-дослідну, організаційну та міжнародну і становить низку основоположних тенденцій професійного вдосконалення вчителя іноземної мови.

Цивільно-правова позиція педагога в процесі формування міжкультурної компетенції учнів сприяє духовноморальному вихованню учнів. Вона заснована на сприйнятті іноземної мови та культури як природної частини життя сучасної людини і є важливим компонентом його професійної діяльності. При цьому іншомовна освіта в новому соціокультурному і політичному контексті постає одним із ключових чинників, що формують почуття громадянина і патріота своєї Батьківщини.

Учитель іноземної мови повинен відбирати або розробляти такий навчально-методичний матеріал, який розвиває здатність і готовність учнів рівноправно взаємодіяти з представниками інших лінгвоетнокультур, примножуючи свій національний потенціал в умовах інтернаціоналізації та глобалізації.

Ідея Я. А. Коменського про те, що «все, що знаходиться у взаємному зв'язку, повинно викладатися в такому ж зв'язку», реалізується в процесі розробки інноваційних моделей і програм підвищення кваліфрікації, які об'єднують, перш за все, наукову, методичну та навчальну діяльність вчителя.

Розробка інноваційних моделей і програм підвищення кваліфікації, що відповідають цілісним вимогам до системи підвищення кваліфікації всіх рівнів педагогічних працівників, у тому числі вчителів англійської мови, представлена такими заходами:

- реалізація вимог чинного законодавства в сфері освіти під час навчання іноземних мов у різних типах освітніх закладів;

- інтерактивні освітні технології у викладанні іноземних мов;

- підготовка вчителя іноземної мови до роботи з електронними освітніми ресурсами;

- навчання іноземним мовам дітей дошкільного віку як одна з умов успішного розвитку сучасного дошкільника тощо.

Ціннісний потенціал сучасних освітніх технологій, що обґрунтовує вибір нових підходів і методів іншомовної освіти, включає наступні аспекти:

- реалізація освітніх програм із застосуванням електронного навчання, з використанням відео-лекцій та інших ресурсів;

- використання очно-заочної форми навчання із застосуванням бально-рейтингової і накопичувальної систем проходження курсів підвищення кваліфікації, а також дистанційних освітніх технологій;

- упровадження технології змішаного навчання (blended learning) в систему іншомовної освіти і в систему підвищення кваліфрікації в тому числі;

- використання мережевої форми реалізації освітніх програм.

Проведення науково-практичних заходів (конференцій, семінарів, вебінарів), у тому числі й міжнародних, сприяє апробації, популяризації та обміну дидактико-методичними розробками вчителів-учасників заходів, що розкривають аксіологічні аспекти змісту іншомовної освіти. Залучення вчителів і молодих дослідників до публікації результатів власної дослідницької роботи стає певним фактором їхнього професійного самовдосконалення, ціннісного самовизначення вчителя іноземної мови, створення умов для мотивації до самоосвіти, ефективної професійної діяльності, фрормування, розвитку і забезпечення діяльності професійних співтовариств учителів / викладачів іноземних мов із метою інформування та здійснення науково-методичної підтримки фахівців іншомовної освіти.

\section{ВИСНОВКИ ТА ПЕРСПЕКТИВИ ПОДАЛЬШИХ ДОСЛІДЖЕНЬ}

Проаналізовані підходи та, відповідно, концепції організації професійного розвитку учителів англійської мови, на нашу думку, є спробою відповісти на виклики сучасності в потребі педагога-професіонала як головної рушійної сили в суспільстві. Також убачаємо позитив в оптимальному поєднанні всіх зазначених підходів, які значною мірою доповнюють один одного.

\section{СПИСОК ВИКОРИСТАНИХ ДЖЕРЕЛ}

[1] Вознюк О. В. Інтегративний підхід до професійного розвитку особистості педагога в умовах цивілізаційних змін. Науковий часопис НПУ імені М. Драгоманова. 2010. Вип. 12 (22). С. 17-20. URL: http://eprints.zu.edu.ua/8418/1/. 
[2] Гулай О. І. Компетентнісний підхід як основа нової парадигми освіти. Вісник Національної академії Державної при-кордонної служби України. 2009. № 2. Серія «Педагогічні науки». URL: http://www.nbuv.gov.ua/ old_jrn/e-journals/ Vnadps/2009_2/09goinpo.pdf.

[3] Данилова Г. С. Педагогічний професіоналізм у контексті акмеології. Педагогічна освіта : теорія і практика: зб. наук. праць. К.: КМПУ ім. Б. Грінченка,2006. №5.С. 74-80.

[4] Корнеева Л.Н.Психологический аспект влияния профессиональной деятельности на личности. М.: Просвещение, 1991. 218 с.

[5] Лабудько С. П. Компетентнісний підхід до вибору педагогічних технологій у системі професійної освіти. Професійна осві-та: методологія, практика, інновації : матеріали регіон. наук.-практ. конф. Суми : РВВ СОІППО, 2007. С. 90-94.

[6] Михайлов А. В. Школа как самообучающаяся организация. Непрерывное образование: XXI век. Bыпуск 1, 2013, DOI: 10.15393/j5.art.2013.1947

[7] Ніколенко Л. Модернізація післядипломної педагогічної освіти в контексті особистісно орієнтованого підходу. Післяди-пломна освіта в Україні. 2007. №2. С. 38-41.

[8] Огієнко О.І. Акмеологічний підхід у контексті освіти дорослих. Філософсьькі, психологічні, аксіологічні контексти педагогіч-ної майстерності. URL: http://lib.iitta.gov.ua/6043/1.pdf.

[9] Протасова Н. Андрагогічна ідея і післядипломна освіта: постановка проблеми. Шлях освіти. 1998. №3. С. 13-15.

[10] Cox J. 15 Professional Development Skills for Modern Teachers. URL: http://www.teachhub.com/15-professional-development -skillsmodern-teachers

[11] Creating Effective Teaching and Learning Environments: First Results from TALIS. URL: http//www.oecd.org/edu/talis/firstresults

[12] Professional development. The Glossary of Education Reform. URL: https://www.edglossary.org/professional-development

\section{REFERENCES (TRANSLATED AND TRANSLITERATED)}

[1] Voznyuk O. V. Intehratyvnyy pidkhid do profesiynoho rozvytku osobystosti pedahoha $v$ umovakh tsyvilizatsiynykh zmin (Integrative approach to the professional development of the personality of the teacher in the conditions of civilizational changes.). Naukovyy chasopys NPU imeni M. Drahomanova. 2010. Vol. 12 (22). pp. 17-20. (in Ukrainian)

[2] Hulay O. I. Kompetentnisnyy pidkhid yak osnova novoyi paradyhmy osvity (Competency approach as the basis of a new education paradigm.). Visnyk Natsional noyi akademiyi Derzhavnoyi prykordonnoyi sluzhby Ukrayiny. 2009. № 2. Seriya «Pedahohichni nauky». URL: http://www.nbuv.gov.ua/ old_jrn/e- (in Ukrainian)

[3] Danylova H. S. Pedahohichnyy profesionalizm u konteksti akmeolohiyi (Pedagogical professionalism in the context of acmeology). Pedahohichna osvita : teoriya i praktyka: zb. nauk. prats. K.: KMPU im. B. Hrinchenka, 2006. № 5. pp. 74-80. (in Ukrainian)

[4] Korneyeva L. N. Psikhologicheskiy aspekt vliyaniya professional'noy deyatel'nosti na lichnosti (The psychological aspect of the influence of professional activity on the individual). M.: Prosveshcheniye, 1991. 218 p. (in Ukrainian)

[5] Labudko S. P. Kompetentnisnyy pidkhid do vyboru pedahohichnykh tekhnolohiy u systemi profesiynoyi osvity (Competency approach to the choice of pedagogical technologies in the system of vocational education). Profesiyna osvita: metodolohiya, praktyka, innovatsiyi : materialy rehion. nauk.-prakt. konf. Sumy : RVV SOIPPO, 2007. pp. 90-94. (in Ukrainian)

[6] Mikhaylov A. V. Shkola kak samoobuchayushchayasya organizatsiya (School as a self-learning organization). Nepreryvnoye obrazovaniye: XXI vek. Vol. 1, 2013, DOI: 10.15393/j5.art.2013.1947 (in Russian)

[7] Nikolenko L. Modernizatsiya pislyadyplomnoyi pedahohichnoyi osvity v konteksti osobystisno oriyentovanoho pidkhodu (Modernization of postgraduate pedagogical education in the context of a personally oriented approach). Pislyadyplomna osvita v Ukrayini. 2007 . №2. pp. 38-41. (in Ukrainian)

[8] Ohiyenko O. I. Akmeolohichnyy pidkhid u konteksti osvity doroslykh (Acmeological approach in the context of adult education). Filosofski, psykholohichni, aksiolohichni konteksty pedahohichnoyi maysternosti. URL: http://lib.iitta.gov.ua/6043/1.pdf. (in Ukrainian)

[9] Protasova N. Andrahohichna ideya i pislyadyplomna osvita: postanovka problem (Andragogic idea and postgraduate education: problem statement). Shlyakh osvity. 1998. №3. pp. 13-15. (in Ukrainian)

[10] Cox J. 15 Professional Development Skills for Modern Teachers. URL: http://www.teachhub.com/15-professional-development-skillsmodern-teachers (in English)

[11] Creating Effective Teaching and Learning Environments: First Results from TALIS. URL: http//www.oecd.org/edu/talis/ firstresults (in English)

[12] Professional development. The Glossary of Education Reform. URL: https://www.edglossary.org/professional-development (in English) 